\title{
中国における大学日本語専攻課程教育の政策的動向 \\ Policy Trends in Japanese Major Programs in China
}

\section{楊 秀娥 中山大学}

\section{要旨}

本稿は、中国の大学日本語専攻課程を対象とする教育政策を分析・比較することで、 大学日本語専攻課程教育の政策的動向を明らかにすることを目的とする。調查対象は、 2000 年前後に発行された『高等教育日本語専攻基礎段階教育大綱』（2000）および 『高等教育日本語専攻高学年段階教育大綱』（2001）のセットと、その約 20 年後の 2018 年に発行された「外国語文学類教育の国家標準」（2018）である。異なる2つの 時代の教育政策を、(1)政策作成の背景、(2)政策の位置付け、(3)日本語専攻課程の学科 属性、(4)日本語専攻課程の教育目標、(5)日本語専攻課程のカリキュラム、(6)教育方法 という 6 つの面から分析・比較した。また、日本語専攻課程教育が国家の主導、英語 類専攻のリードで発展してきた点、学科属性と学士教育の再評価されてきている点、 そして、人材像とコースが多様化している点について考察を行った。ただし、教育 内容、教育方法の早期改善の実現性については懸念を払拭できない。

キーワード :

大学日本語専攻課程教育、教育政策、政策的動向、大綱、国家標準 


\section{中国における大学日本語専攻課程教育の政策的動向}

\section{楊 秀娥 中山大学}

\section{1. はじめに}

世界一多くの日本語学習者を有している中国の日本語教育には、高等教育機関で 学ぶ学習者が多いという特徵がある（国際交流基金 2016）。なかでも大学で日本語、 日本文学、日本社会・文化などについて学び、4 年で学士の学位を取得する学習者を 対象とする日本語専攻課程は、多くの大学に設置されている。中国の大学日本語専攻 課程教育は、学習者の数から見ても、日本語や日本文学など学習内容の広さ・深さから 見ても、世界の日本語教育において際立った存在であると言えよう。本稿は、2000年 前後と、2018 年現在という異なる 2 つの時代に作成された、中国の大学日本語専攻 課程を対象とする教育政策を分析・比較し、中国の大学日本語専攻課程の政策的 動向を明らかにすることを目的とする。学士学位の授与を伴う中国以外の国・地域に おける大学日本語専攻課程教育の参考になれば幸いである。

\section{2.これまでの中国の大学日本語専攻課程教育}

中国における大学日本語専攻課程教育の発足は、清の時代に政府が設置した外国語 学校である京師同文館において、1896 年に設立された東方館であるという（付 1986）。 新中国が成立した 1949 年からの大学日本語専攻課程教育の発展は、いくつかの研究 によって段階別に区分されている。例えば、修・李（2011）は、日本語専攻課程を設置 する大学数、学習者数に着眼し、日本語専攻課程を設置した大学がまだ少なかった 1949 年〜1972 年の期間を第一発展期、多くの大学で日本語専攻課程や修士課程が 開始された 1972 年〜1999 年の期間を第二発展期、大学学生募集定員の拡大という 政策のもと、日本語専攻課程が多く設置され、日本語専攻生が大幅に増加した 1999 年 〜2012 年の期間を第三の発展期と称している。さらに、2012 年から現在に至るまで を新しい発展期としている（修 2018）。また、喬（2013）は、日本語専攻課程教育を、 「1949 年〜 1977 年」特定分野の実務人材を育成する「政治主導型」の段階、「1978 年〜 1999 年」エリート人材を育成する「経済需要型」の段階、「2000 年〜2012 年上半期 現在」複合型人材を育成する「急速増長型」の段階に分けることができるとしている。

他方、日本語専攻課程教育は目覚ましい発展を遂げるとともに、中国の社会発展、 経済成長、中日関係の変化、日本語専攻生の就職競争の激化などの影響から、新たな 問題も多く生まれている。李・修（2018:55）では、(1)学生急増と教育水準の質保証 の矛盾、(2)講義の多様化と主幹講義の矛盾、(3)卒論テーマの多様化と指導の矛盾、 
(4)教育資源不均衡と情報共有不可能、(5)日本語教育のための言語研究 (第二言語習得、 認知言語学など）の必要性、6変動の中にある中日関係（文化の相互理解）などが 挙げられている。また、道具とされる日本語専攻課程の学科属性、教師主導による 知識伝授という教育方法なども指摘されている（陈 2012、葛 2014、楊 2018 など）。

\section{3. 調査対象と調査方法}

\section{1 調查対象}

本稿では、中国の日本語専攻課程教育の政策的動向を明らかにするため、日本語 専攻課程を対象とする重要な教育政策について調査する。調査対象は、表 1 の通りで ある。

表 1 調查対象になる日本語専攻課程の教育政策

\begin{tabular}{|c|c|c|c|}
\hline 本稿での略称 & 教育政策 & 出版年 & 制定者 \\
\hline $\begin{array}{l}\text { 『基礎段階 } \\
\text { 大綱』（2001） }\end{array}$ & $\begin{array}{l}\text { 『高等教育日本語専攻基礎段階教育大綱』 } \\
\text { (原語 : 《高等院校日语专业基础阶段教学大纲》) }\end{array}$ & 2001 & $\begin{array}{l}\text { 中国教育部 } \\
\text { 高等学校外 }\end{array}$ \\
\hline $\begin{array}{l}\text { 『高学年段階 } \\
\text { 大綱』（2000） }\end{array}$ & $\begin{array}{l}\text { 『高等教育日本語専攻高学年段階教育大綱』 } \\
\text { (原語：《高等院校日语专业高年级阶段教学大纲》) }\end{array}$ & 2000 & $\begin{array}{l}\text { 语专业教学 } \\
\text { 指导委员会 } \\
\text { 日语组 }\end{array}$ \\
\hline $\begin{array}{l}\text { 「外国語国家 } \\
\text { 標準」（2018） }\end{array}$ & $\begin{array}{l}\text { 「外国語文学類教育の国家標準」 } \\
\text { (原語：〈外国语言文学类教学质量国家标准〉) }\end{array}$ & 2018 & $\begin{array}{l}\text { 中国教育部 } \\
\text { 高等学校外 } \\
\text { 语专业教学 } \\
\text { 指导委员会 }\end{array}$ \\
\hline
\end{tabular}

『基礎段階大綱』（2001） と『高学年段階大綱』（2000）は、1 つのセットで、 およそ 20 年前に作られ、中国の日本語専攻課程教育を規定している現役の教育大綱 である。2 つの大綱は、それぞれ 363 ページと 407 ページからなる A5 サイズの書籍 であるが、育成目標、授業内容、授業の要求、測定などを記した本文はそれぞれ 10 ページと 13 ページに過ぎず、紙幅の大半を占めるのは、音声、語彙、文法、文型、 機能・概念などの付録である。本稿では、2つの大綱の本文を分析の対象とする。

一方、「外国語国家標準」（2018）は、日本語、英語、ロシア語などの外国語を 専攻の対象とする外国語専攻課程教育の今後のあり方を規定した新しい政策である。 
「外国語国家標準」（2018）は、2018 年に中国教育部高等教育指導委員会が公布した 『普通高等教育本科 ${ }^{1}$ 専攻類教育の国家標準』 ${ }^{2}$ (原語 : 《普通高等学校本科专业类 教学质量国家标准》）（以下、『高等教育国家標準』（2018）と略す）内の1つの章 である。A4 サイズの『高等教育国家標準』（2018）において 5 ページ相当を占めて おり、概論、適用の専攻、人材育成の目標、人材育成の規格、カリキュラム、教師、 環境、質管理、用語説明という9つの項目から構成されている。

『基礎段階大綱』（2001）と『高学年段階大綱』（2000）について分析した研究に は、冷（2011）、葛（2012、2014）などがあるが、今後の日本語専攻課程教育に大きく 影響する「外国語国家標準」（2018）を取り上げた研究はまだ非常に少ない。前掲した 李・修（2018）は、「外国語国家標準」（2018）に触れ、その特徵として、(1)教育内容 の重視、(2)多様性の重視、(3)異文化コミュニケーション能力の重視、(4)講義の履修 項目と内容の見直しを挙げている。本稿では、2000 年前後に作成された『基礎段階 大綱』（2001）、『高学年段階大綱』（2000）のセットと、2018 年に作成された「外国 語国家標準」（2018）の詳細な比較と考察を行う。『基礎段階大綱』（2001）、『高 学年段階大綱』（2000）の本文、「外国語国家標準」（2018）は、ともに日本語専攻 課程、またはそれを含む外国語専攻課程の教育目標やカリキュラム、教育方法などに ついて規定しているため、それらの分析・比較から日本語専攻課程教育の政策的動向 を見ることができると考える。

\section{2 調查方法}

上記で述べた 2 つ時代の教育政策のテキストを中心に用いて、内容分析の手法で 調査した。内容分析（content analysis）とは、データをもとにそこからそれが組み こまれた文脈に対して再現可能でかつ妥当な推論を行うための一つの調査技法で ある（Krippendorff1980）。本研究では、2つの時代の教育政策（前書き、後書きなど も含む）を細かく比較し、関連性の高いその他の教育政策、文献と合わせ、まず (1)政策作成の背景をまとめた。そして、2 つの時代の教育政策のテキストから、 (2)政策の位置付け、(3)日本語専攻課程の学科属性、(4)日本語専攻課程の教育目標、 (5)日本語専攻課程のカリキュラム、6教育方法という5 つの面を抽出し、それ ぞれの内容について分析・比較した。

\footnotetext{
本科とは、学士学位の取得が伴う 4 年制大学を指す。

2 『高等教育国家標準』(2018) には、外国語文学類、哲学、経済学、医学技術など 125 の専攻類 に関する国家標準がそろっている。外国語文学類を対象とする「外国語国家標準」（2018）は、 英語、日本語、ロシア語など 68 の専攻を範囲にしている。
} 


\section{4. 調査結果}

\section{1 政策作成の背景}

『基礎段階大綱』（2001）と『高学年段階大綱』（2000）のセット、および「外国 語国家標準」（2018）は、中国教育部の明確な指示を発端として誕生したものである。 そして、それぞれの時代の大綱や国家標準における具体的内容の決定は、外国語専攻 教育に現れた問題点、学習者の変化、人材育成の要求の変化などから大きな影響を 受けている。

『基礎段階大綱』（2001）と『高学年段階大綱』（2000）の制定には、上述の通り、 中国教育部の要請が大きく関係している。中国教育部が 1998 年に発行した「21 世紀 に向けた外国語専攻教育における学士教育改革に関する若干の意見」（原語 : 《关于 外语专业面向 21 世纪本科教育改革的若干意见》）（以下、『若干の意見』（1998） と略す）が、上記の 2 つの大綱に大きな影響を与えている。『若干の意見』（1998）は、 教育部高教司（高等教育部門）が公開した通達である。その中で、「外国語専攻 教育は、単科のスコラ的 ${ }^{3}$ 人材育成パターンから、広口径 ${ }^{4}$ 、応用性、複合型人材育成 パターンに転換しなければならない」（p.1）と人材育成パターンの方向性を示して いる。『基礎段階大綱』（2001）では、『若干の意見』（1998）についての記載はない ものの、『高学年段階大綱』（2000:1）では、「21 世紀に入って、我が国の高校教育 における日本語専攻課程の人材育成モデルに対し新しい要求が提起されている。

(中略) 新しく作ったこの日本語専攻課程高学年段階大綱は、『若干の意見』(1998) を実践、継続するための重要な保障になる」と明確に述べられている。このように、 2000 年前後に作成された大綱は、中国教育部の方針を反映している。

また、中国における外国語/日本語専攻課程教育の変化も指摘されている。『基礎 段階大綱』（2001）の前書きでは、「第一に、日本語専攻課程を設置する大学が急速に 増加し、学習者数が大幅に増加した」、そして、「第二に、国内外情勢の変化にしたがい、 我が国の日本語教育の目標、内容、方法、手段なども変わってきている。例えば、 言語応用能力、異文化コミュニケーション能力は 21 世紀の日本語教育の重要な目標 になる」と記されている。上記の『若干の意見』（1998:1）でも、「外国語人材に対 する社会の需要が多元的になり、外国語専攻課程の人材への需要は縮小しつつある。 従来の単一の外国語技能型、基礎技能型の人材はもう市場経済の需要には対応でき なくなってきた」と述べられている。

\footnotetext{
教師がテキストを使って詳しく説明するという意味である。

幅広い知識を持つという意味である。 


\section{中国における大学日本語専攻課程教育の政策的動向}

「外国語国家標準」（2018）が記載されている『高等教育国家標準』（2018）は、 高等教育の質向上という中国教育部の要求のもとで制定されている。『高等教育国家 標準』（2018）の前書きには「教育の質を保証するシステムを作成、健全化するため」 という一文が記されており、中国教育部の要求の具体的な詳細は「外国語国家標準」 （2018）の作成者である中国教育部高等教育外国語専攻指導委員会（原語：中国教育 部高等学校外语专业教学指导委员会）のコアメンバーが執筆した文献（钟 2015、 仲 2015、冯 2017 など）から読み取れる。21 世紀以来、中国の高等教育は大規模な発展 を遂げている。2010 年に、『国家中長期教育改革と発展計画の綱要（2010-2020 年）』

(原語: 国家中长期教育改革和发展规划纲要 (2010-2020 年)) (以下、『綱要 (2010-2020)』 （2010）とする）が公表され、高等教育にあたって、「質の向上は、高等教育発展の ための中核的なタスクであり、高等教育で国力を高めるための基本要求となる」と 明記された。さらに、2012 年に公表された『全面的に高等教育の質を高めるための 教育部の若干の意見』（原語: 教育部关于全面提高高等教育质量的若干意见）（以下、 『若干の意見』（2012）とする）では、「質の向上に重点を置いた内包的な発展ルート を歩む」（p.1）、「人材育成の質的標準システムを完備する」（p.3）ことなどが指示 されている。それに反応するかたちで、2013 年 9 月から、中国教育部高等教育外国 語専攻指導委員会の委託を受け、英語専攻課程教育をはじめとした各外国語専攻課程 教育の専門家により、それぞれの外国語専攻課程教育の国家標準の制定が始まった。

また、「外国語国家標準」（2018）の作成は、中国の外国語専攻課程教育の発展と いう要求に応じるものでもある。中国の高等教育の規模拡大とともに、外国語専攻課 程の開設も大幅に増え、2013 年現在、外国語専攻生は 81 万人にも達している(钟 2015)。 しかし外国語専攻課程教育の増加に伴い、問題点も露呈している。言語知識の注入と 言語技能の訓練が中心となり、教師の「教える」が重視される点（胡・孙 2006、黄 2009 など）、教育が同質化してしまい、特色に欠ける点、学生の学力の低下、学科 の位置付けが曖昧で人材育成の要求に合わない点（钟 2015、仲 2015、冯 2016 など） などが指摘されている。

\section{2 政策の位置付け}

$2 つ の$ 時代の教育政策は、ともに全国の日本語専攻課程教育を衰引、管理する、国 レベルの政策であり、非常に重要な位置を占めている。

『基礎段階大綱』（2001:1）は「基礎段階におけるカリキュラムの制定、教材の 編纂、測定の分析、教育の評価に根拠を提供し」、『高学年段階大綱』（2000:1）は 「教育の実施、教材の編纂、教育の質評価の根拠になっている」。2つの大綱は 1 つ のセットとして、日本語専攻課程教育を指導する役割を果たしている。 
「外国語国家標準」（2018）は、「全国の大学外国語専攻課程教育の新設、実践、 評価を行う際のスタンダーズ」（p.90）に位置付けされ、「外国語専攻課程を有する 各大学は、当標準にしたがい、社会的なニーズにこたえ、大学各自の位置付けと特色 を反映した人材育成プランを作成す心゙きである」と規定している。各大学は、今後 「外国語国家標準」（2018）にしたがって各自の人材育成標準とカリキュラムを作成 することが要求される。

\section{3 日本語専攻課程の学科属性}

日本語専攻課程の学科属性について、『基礎段階大綱』（2001）と『高学年段階 大綱』（2000）に明確な記述は見られなかった。一方、「外国語国家標準」（2018:90） の冒頭には、「外国語専攻課程は、中国の高等教育における人文社会科学系の重要な 一部である」と記されている。専攻課程の学科属性は、『高等教育国家標準』(2018) の必須項目でないものの、外国語専攻課程が人文社会科学であるという学科属性が ここで明らかにされている。そして「外国語専攻課程は、外国語言語学、外国文学、 翻訳学、国別・地域研究、対照文学、異文化研究などを基礎に学際的な性質を持ち、 社会発展のニーズに合わせて他の関連専攻と連携した複合型専攻課程を作ることが できる」と書かれており、外国語専攻課程がほかの専攻と連携できるという学際的な 特色も強調されている。

\section{4 日本語専攻課程の教育目標}

『基礎段階大綱』（2001）と『高学年段階大綱』（2000）では、教育目標として 異文化コミュニケーション能力が提示されているものの、(1)日本語についての知識、 日本社会文化、日本文学などの日本についての知識の学習、(2)「聞く・話す・読む・ 書く・訳す」といった 5 技能の運用能力の向上の 2 点が特に重視されていることが 見て取れる。『基礎段階大綱』（2001：1）において、「学生がしっかり勉強し、日本語 の基礎知識を身につけるように導く。「聞く・話す・読む・書く」の技能を訓練する。 言語運用能力を育成する。学生の社会文化知識を豊かにし、文化理解能力を育成する。 高学年での勉強のために堅固な基礎を築く」と書かれている。基礎段階の教育目標は、 日本語の知識を身につけさせ、聞く・話す・読む・書く」技能を訓練することである ことがうかがえる。また、『高学年段階大綱』（2000：1-2）の記述から、高学年段階 では、日本語専攻生の就職に向けて、「引き続き言語の基礎を鍛え、日本語の実践能力 を高め、文化知識を充実させ、知識をさらに広め」、「訳す」ことを加えた日本語運用 能力の向上が目標とされていることがわかる。 
「外国語国家標準」（2018）の「人材育成の目標」という項目では、どのような人材 を育成すべきかについて総合的に規定されており、そこでは外国語専攻課程教育で 育成する人材は、「外国語専門人材」と「複合型外国語人材」の 2 種類で、総合素養、 外国語やその関連分野における能力と知識を持っており、社会のニーズにこたえ られる者とされている。

外国語専攻課程教育は、質の高い総合的素養、しつかりとした外国語の基礎と専門的な知識・ 能力、関連分野の知識を持ち、我が国の対外交流、国と地域の経済発展、外国に関連した職業、 外国語教育、学術研究の需要に適応できる外国語専門人材と複合型外国語人材を育成する。

（「外国語国家標準」（2018:92））

さらに、「人材育成の規格」という項目では、素養、知識、能力について詳しく記述 されている。表 2 に素養、知識、能力の各規格をキーワードごとにまとめた。「外国語 国家標準」（2018）は、外国語や外国に関連する知識、能力だけでなく、大学生として 持つべき素養をはじめ、広い視野から外国語専攻生が持つべき素養、知識、能力を 規定している。

\section{表 2 「外国語国家標準」（2018）で規定される人材育成の規格}

\begin{tabular}{|c|c|}
\hline $\begin{array}{l}\text { 人材育成 } \\
\text { の規格 }\end{array}$ & キーワード \\
\hline 素養 & $\begin{array}{l}\text { 正確な世界観・人生観・価値観、良好な道徳品性、中国への想いと国際的視野、 } \\
\text { 社会的責任感、人文・科学素養、チームワーク精神、創造精神、 } \\
\text { 基本的専門素養 }\end{array}$ \\
\hline 知識 & $\begin{array}{l}\text { 身に付けるべき知識 : 外国語の知識、外国文学の知識、国別・地域の知識 } \\
\text { 把握しておくべき知識 : 中国語・中国文化の知識 } \\
\text { ある程度把握しておくべき知識 : 関連分野の知識、人文系・自然科学系の基礎知識 }\end{array}$ \\
\hline 能力 & $\begin{array}{c}\text { 身に付けるべき能力 : 外国語の運用能力、文学の鑑賞能力、異文化 } \\
\text { コミュニケーション能力、クリティカル・シンキング能力 } \\
\text { ある程度身に付けるべき能力 : 研究能力、創造能力、ICT 応用能力、自律学習能力、 } \\
\text { 実践能力 }\end{array}$ \\
\hline
\end{tabular}




\section{5 日本語専攻課程のカリキュラム}

日本語専攻課程のカリキュラムについて、『基礎段階大綱』（2001）に具体的な記述 ないものの、「基礎段階の学習内容は、音声、文字・語彙、文法、文型、機能・概念、 社会文化という 6 つの項目」（p.2）で構成されており、「言語の基礎能力訓練は、基礎 段階教育の中心である。基礎能力の訓練には、言語知識（音声、文字・語彙、文法 など）と言語技能（聞く・話す・読む・書くなど）の訓練がある」（p.6）と記されて いる。これらの記述から、言語知識（音声、文字・語彙、文法など）と言語技能 （聞く・話す・読む・書くなど）の訓練は、基礎段階の主要テーマであることがわかる。 これらの知識と技能を習得させるためのコースは、「精読」「聴解」「読解」「作文」 「会話」などであろう。一方、『高学年段階大綱』（2000）では、カリキュラムを次の ような 4 種類のコース群に分けて記載している。そのほか、卒業論文と卒業インターン シップについても規定されている。

日本語総合技能コース群 : 精読、氾読、新聞選読、作文、通訳・翻訳など

日本語学コース群：言語学概論、日本語概論、国別言語学、古典語法、日本社会と 言語文化など

日本文学コース群 : 文学作品の選読、文学史、日本文学鑑賞など

日本社会文化コース群：日本文化史、日本事情、日本経済など

卒業論文：6000〜8000 字、原則的に日本語で執筆

卒業インターンシップ : 実習報告の提出

「外国語国家標準」（2018）では、外国語専攻課程に 150～180の単位、2400～2900 時間のコースが設置されると規定されている。カリキュラムは、教養教育コース群、 専門コアコース群、方向性コース群、実践的コース群、卒業論文という 5 種類のコース 群から構成され、このカリキュラムを通して、「能力の育成と知識の構築、特に異文化 能力、クリティカル・シンキング能力と創造性の育成を重視し」、そして、「経済的 社会的な需要にこたえられる動態的なカリキュラムの調整体制が備わるべき」(p.92) と規定されている。5 種類のコース群の詳細を表 3 に示した。 


\section{表 3 「外国語国家標準」（2018）におけるカリキュラム}

\begin{tabular}{|c|c|}
\hline コース群 & 詳 細 \\
\hline $\begin{array}{l}\text { 教養教育 } \\
\text { コース群 }\end{array}$ & $\begin{array}{c}\text { 共通基礎コース：思想政治理論、情報技術、体育と健康、軍事理論と訓練、 } \\
\text { ベンチャー教育、第二外国語など } \\
\text { 大学レベルの教養教育コース群 : 人文社会科学と自然科学についてのコース }\end{array}$ \\
\hline $\begin{array}{l}\text { 専門コア } \\
\text { コース群 }\end{array}$ & $\begin{array}{l}\text { 外国語技能コースと専門知識コースに分け、全学習時間数の } 50 \% \text { ～} 85 \% \text { を } \\
\text { 占めることが望ましい。 } \\
\text { 日本語専攻の場合： } \\
\text { 基礎日本語、上級日本語、日本語会話、視る・聞く・話すための日本語、 } \\
\text { 日本語スピーチ・ディベート、日本語読解、日本語基礎ライティング、 } \\
\text { 翻訳理論と実践、通訳理論と実践、日本語学概論、日本文学概論、日本事情、 } \\
\text { 異文化コミュニケーション、アカデミック・ライティングと研究方法など }\end{array}$ \\
\hline $\begin{array}{l}\text { 方向性 } \\
\text { コース群 }\end{array}$ & $\begin{array}{l}\text { 各大学が、外国語専攻課程の人材育成目標と育成規格にしたがい、次の方向性 } \\
\text { コース群を設置することができる。 } \\
\text { 外国文学、外国語学、翻訳学、外国語教育、国別・地域研究、対照文学と } \\
\text { 異文化研究、目的別外国語など }\end{array}$ \\
\hline $\begin{array}{l}\text { 実践的 } \\
\text { コース群 }\end{array}$ & インターンシップ、ベンチャー教育、社会的実践、国際交流活動 \\
\hline 卒業論文 & $\begin{array}{l}\text { 形式 : 学術論文、翻訳作品、実践報告、調査報告、ケーススタディー } \\
\text { 執筆言語：一般的には専攻の外国語を使用（翻訳作品を除く） }\end{array}$ \\
\hline
\end{tabular}

※この表は「外国語国家標準」（2018:92-94）をもとに筆者が作成した。

2 つの時代の教育政策におけるカリキュラムの比較から、次の 2 点が読み取れる。 まず、2000 年前後の『基礎段階大綱』（2001）、『高学年段階大綱』（2000）と比べた とき、「外国語国家標準」（2018）は、カリキュラムのコース群の分類と目的が明確 になっている。種類だけでなく、コース内の選択肢も多く、例えば、「専門コアコース 群」には、これまでなかった日本語スピーチとディベート、異文化コミュニケーション、 アカデミック・ライティングと研究方法などのコースが含まれている。また方向性 コース群では、これまでの言語学、文学に加え、翻訳学、外国語教育、国別・地域 研究、対照文学と異文化研究、目的別外国語などが選択できるようになっている。 実践的コース群と卒業論文の形式もこれまでのような単一の形式ではなく、より多く のパターンが提供されている。 


\section{6 教育方法}

『基礎段階大綱』（2001）と『高学年段階大綱』（2000）から、教師主導による技能 の訓練、知識の説明が勧められていることがうかがえる。『基礎段階大綱』（2001） には、「授業の際に、説明を明快にし、練習をたくさんさせるのが原則」（p.7）、 そして、「教師は知識を伝える存在であると同時に、教室活動を組織する存在でも ある。教師は主導的に役割を果たさなければならない」(p.8) という記述が見られる。 『高学年段階大綱』（2000）では、教師による「紹介」「講義」「説明」を求めており、 カリキュラムではコース群ごとに、教育方法が規定されている。例えば、「日本語総合 技能コース群」の「精読」授業については、「学生が積極的に授業に参加するように 学生の主体性を引き出し、柔軟で多様な教育方法をとるべき」としつつ、「教師は、 文章、文の構造の分析だけでなく、大量の言語的、文化的背景の知識を紹介」（p.3） することが求められる。「日本語学コース群」に関して、「学生に言語学の基本的な 知識を初歩から理解させることが目的であるため、教師の講義が主となる」（p.6） と規定されている。

他方、「外国語国家標準」（2018）では、簡潔な記述ではあるが、啓発的、討論型、 参加型の教育方法を重視する内容が目立つ。「学生の全面的発展と個性的発展を目指す ため、学生、教育目標、教育内容に合わせて、教育方法を選択し、啓発的、討論型、 参加型の教育方法を重視」（p.95）、そして、「現代的教育技術を活用し、教育の効果 を重視する」（p.95）ことが規定されている。

教育方法に関する分析・比較から、2 つの時代で教育政策が重視している主体が 異なる点が読み取れる。『基礎段階大綱』（2001）と『高学年段階大綱』（2000）では、 教師の役割が過度に重視され、教師主導の訓練、説明の重要性が強調されている。 「外国語国家標準」(2018) では、学習者という学習の主体が注目され、学習者の能動性 を発揮させるような、啓発的、討論型、参加型の教育方法が重視されている。

\section{5. 考察}

\section{1 国家主導、英語類専攻リードの日本語専攻課程教育}

2000 年前後と 2018 年現在という 2 つの時代に作成された日本語専攻課程の教育 政策の分析・比較から、日本語専攻課程教育の発展は、中国教育部の主導に基づいた 日本語専攻の専門家の知恵と甚大な努力の成果であると同時に、英語類専攻のリード の結果でもあることがうかがえる。 
2000 年前後に作成された『基礎段階大綱』（2001）と『高学年段階大綱』（2000） のセットは、教育部がその数年前に公表した外国語専攻を対象とする『若干の意見』 （1998）から大きな影響を受けている。また 2018 年に作成された「外国語国家標準」 （2018）は、教育部が公表した、教育全般を対象とする『綱要（2010-2020）』（2010） と高等教育を対象とする『若干の意見』(2012) からの指示のもとで作成されている。 それらの経緯で作られた $2 つ の$ 時代の教育政策は、ともに全国の日本語専攻課程教育 を指導、評価する国レベルの重要な政策と位置付けられている。

そして、日本語専攻課程の教育政策は、日本語専攻の専門家による成果であり、 英語類専攻にリードされた結果でもある。2000 年前後に作成された『基礎段階大綱』 （2001）、『高学年段階大綱』（2000）の前書きから、この2つの教育政策のセットは、 日本語専攻の専門家が会議やシンポジウムを何度も重ねて生み出した成果である点 がうかがえる。また、詳細なカリキュラム、日本語専攻に特化した付録などからも、 日本語専攻の専門家の知恵と努力が伝わってくる。それに対して、「外国語国家標準」

（2018）にあたっては、2013 年 9 月から英語、ビジネス英語、翻訳という 3 つの 英語類専攻の専門家がそれぞれの専攻の国家標準を作ったうえで、それらの仮の国家 標準を手本に、日本語、フランス語など英語類以外の外国語専攻の専門家が各外国語 専攻向けの国家標準を作っていたという（钟 2015）。その後の 2018 年に、各外国語 専攻が統合された形で、『高等教育国家標準』（2018）内の1つの章として「外国語 国家標準」(2018) が公表されている。なお、5 ページ相当の「外国語国家標準」(2018) に、日本語に特化した内容は、専門コアコース群以外見られていない。以上の 2 点から、 「外国語国家標準」（2018）は、英語類専攻に強くリードされていることが推測される。 発展がより進んでいる英語類専攻の力を借りられること自体は非常に良いことで あるが、ゼロビギナーを対象とする日本語専攻教育の特殊性などが看過される懸念も 存在する。

\section{2 学科属性と学士教育の再評価}

2 つの時代の教育政策の分析・比較によって、日本語専攻課程教育が人文社会 科学であるという学科属性、そして、学士教育であるという性質の再評価が強く感じ られる。

前述したように、2000 年前後に作成された教育政策では、日本語専攻課程の学科 属性についての言及はなかったが、2018 年に作成された教育政策では、外国語専攻 課程が人文社会科学であるという学科属性が強調されている。もともと、日本語や 
英語などの外国語専攻課程は、『普通大学本科専攻科目目録（2012 年）』（原語： 《普通高等学校本科专业目录(2012 年)》)にある「文学」の下位にある「外国言語文学」 に属しているため、人文社会科学系になるはずである。しかし、日本語専攻課程教育 は、単なる道具としての日本語の伝授と訓練を過度に重視しており、日本語専攻課程 の人文性が失われるという指摘が絶えなかった（陈 2012、楊 2018 など）。日本語 専攻課程をリードする英語専攻課程に対しても、同様の指摘がなされている。学生の 長期的な人間的成長よりも、学んだ知識の短期的な即効性といった道具性を過度に 重視する点は、外国語専攻課程教育だけでなく、中国の大学教育全体の課題であろう

（孙 2014）。道具性の過度な重視が問題視されたことにより、新しく公表された「外国 語国家標準」（2018）では、外国語専攻課程が人文社会科学系の重要な一部であること が強調されたと考えられる。

また、教育目標の設定に、日本語専攻課程教育の学士教育としての性質を見ること ができる。教育目標の分析・比較からうかがえるように、2000 年ごろに発行された 大綱は、異文化コミュニケーションを意識しながらも、日本語についての知識、日本 社会文化、日本文学などの日本についての知識と、「聞く・話す・読む・書く・訳す」 といった 5 技能を特に重視している。「外国語国家標準」（2018）は、明確に「外国 語専門人材」、「複合型外国語人材」の 2 つを人材育成の目標にしており、外国語能力 だけでなく、広い視野から学士が持つべき素養、知識、能力の育成が求められている。 これらの教育目標こそが人文社会科学であるという学科属性を表しているように 思われる。

\section{3 人材像とコースの多様化}

本稿の第 2 節で振り返ったように、中国の日本語専攻課程教育は、時代の変化に ともなって、特定分野の実務人材、エリート人材、そして、複合型人材を育成してきて いる（喬 2013）。今後に向けて、「外国語国家標準」（2018）では、明確に「外国語 専門人材」と「複合型外国語人材」を外国語専攻課程教育の人材像と定めている。 各大学の日本語専攻課程では、それぞれの大学の特徵と位置付けに合わせ、教育目標 が選択できるようになっている。

また、「外国語国家標準」（2018）では、カリキュラムの「方向性コース群」から 選択できる多様なコースが挙がっている。そして、2000 年前後の教育政策で定め られていた「卒業インターンシップ」と「卒業論文」に加え、今後、インターンシップ、 ベンチャー教育、社会的実践、国際交流活動などの「実践的コース群」、また、学術 論文、翻訳作品、実践報告、調査報告、ケーススタディなどの「卒業論文」の形式も 選べるようになっている。人材像とコースの設定に与える選択肢は、従来より多く なっている。 


\section{4 教育内容、教育方法への懸念}

「外国語国家標準」（2018）で規定されているように、今後は、従来の教師主導の 訓練、説明ではなく、啓発的、討論型、参加型の教育方法が重視されている。ただ、 カリキュラムで規定されるコースの内容、その内容を実現させる教育方法については、 眯念も残る。これまでになかった日本語スピーチとディベート、異文化コミュニケー ション、アカデミック・ライティングと研究方法といったコース、ベンチャー教育、 社会的実践などといった実践的コース、翻訳作品、実践報告、調査報告などといった 卒業論文が、具体的にじのような形で実践されていくかについても、これから検討し なければならない課題であろう。

また、啓発的、討論型、参加型の教育方法は、中国の日本語教育だけでなく、中国 の外国語教育全体においても模索段階の教育方法である (潘・宋 2016、金 2017 など)。 国家レベルの教育政策によってそれらの方法が重視されることは良いことに違い ないが、全国的に同時に推進することについては、実現性が懸念されている。そして、 具体的にどのような科目でどのように啓発的、討論型、参加型の教育方法を取り入れ たら良いかも明確には記されていない。そのためか、『高等教育国家標準』（2018） が公表されてまもなく 1 年が経っている現在でも、多くの大学は動かずにただ様子を うかがっているだけである。今後、専門家による指導とともに、各大学の日本語専攻 課程の教師が自ら新しい教育政策について学び、実践を重ねることが望まれる。 


\section{参考文献}

陈俊森（2012）试论日语专业的人才培养目标《日语教育与日本学》(2), 1-9

冯光武 (2016) 新一轮英语类专业教育改革:回顾与展望《外语界》（172），12-17

冯光武 (2017) 把握国标精神、找准学校定位、突出专业特色—《高等学校英语专业本科教学质量

国家标准》的实施建议《外语界》（178），2-6

付克（1986） 《中国外語教育史》上海外語教育出版社

高等学校外语专业教学指导委员会英语组（1998） 《关于外语专业面向 21 世纪本科教育改革的若干

意见》教育部高教司

国家中长期教育改革和发展规划纲要工作小组办公室（2010）《国家中长期教育改革和发展规划纲要

(2010-2020 年)》

胡文仲 - 孙有中 (2006) 突出学科特点, 加强人文教育一试论当前英语专业教学改革《外语教学与

研究》 (5), 243-247

黄源深 (2009) 英语专业课程必须彻底干戈一再谈“思辨缺席”.庄智象编《中国外语教育发展战略论坛》

上海外语教育出版社, 292-301

教育部高等学校教学指导委员会（2018） 《普通高等学校本科专业类教学质量国家标准》高等教育 出版社

金玉花（2017）合作学习中大学日语教师的教学观一基于三位大学日语教师的 PAC 分析《日语学习

与研究》 (190)，79-86

冷丽敏 (2011) 关于高等学校外语教育理念的研究与探索一以《高等院校日语专业基础阶段教学大纲》

为对象《日语学习与研究》 (153), 99-106

潘琳琳・宋毅（2016）合作学习与思辨能力的培养《外语与外语教学》（287），97-105

孙有中（2014）英语教育十大关系—英语专业教学质量国家标准的基本原则初探《中国外语教育》

$7(1), 3-10$

修刚（2018）新时代中国专业日语教育的转型与发展《日语学习与研究》(194),75-79

修刚・李运博 (2011) 《中国日语教育概览 1》外语教学与研究出版社

中国教育部高等学校外语专业教学指导委员会日语组（2000）《高等院校日语专业高年级阶段教学

大纲》大连理工大学出版社

中国教育部高等学校外语专业教学指导委员会日语组 (2001)《高等院校日语专业基础阶段教学大纲》

大连理工大学出版社

中华人民共和国教育部（2012）《教育部关于全面提高高等教育质量的若干意见》

中华人民共和国教育部高等教育司《普通高等学校本科专业目录(2012 年)》高等教育出版社

钟美蒜 (2015) 实施本科教学质量国家标准, 推进外语类专业教学改革与发展《外语界》（167），2-6 仲伟合 (2015) 《英语类专业本科教学质量国家标准》指导下的英语类专业创新发展《外语界》(168),

$2-8$

葛茜（2012）「中国の大学日本語専攻教育は何をめざしているか一『教学大綱』の分析から」

『日本語・日本学研究』(2)，33-44

葛茜（2014）「中国の大学日本語専攻教育における教育理念の意味づけと問題点 : 言語教育政策の

分析を中心に」『東京外国語大学日本研究教育年報』（19），1-18

喬頴（2013）「中国の日本語科教育における「人材育成」の系譜」『早稲田日本語教育学』（14）,

$27-48$

国際交流基金 (2016)「2015 年度海外日本語教育機関調查結果」 $<\mathrm{http} / / / w w w . j p f b j . c n / s y s / w p-c o n t e n t /$

uploads/2016/11/2015 jieguoshuoming.pdf $>$ (2018 年 12 月 12 日)

論文 


\section{中国における大学日本語専攻課程教育の政策的動向}

李運博・修剛（2018）「新時代に向かう中国日本語教育の現状と課題」『早稲田日本語教育学』 (24) ,49-57

楊秀娥（2018）『日本語表現力と批判的思考力を育むアカデミック・ライティング教育：中国の 大学の日本語専攻における対話を生かした卒業論文支援を例に』ココ出版

Krippendorff.K (1980) Content Analysis: An Introduction to Its Methodology. 三上俊治・橋元良明・ 椎野信雄訳（2003）『メッセージ分析の技法一「内容分析」への招待』勁草書房

\section{付記}

本研究は、2018 年度中国教育部人文社会科学研究青年基金（18YJC740126）の助成ををいただき ました。ここで感謝の意を表します。 